\title{
РОЛЬ МЕЖСЕМЕЙНОГО ОБМЕНА В СИСТЕМЕ МАТЕРИАЛЬНОЙ ПОДДЕРЖКИ И УХОДА ЗА ПОЖИЛЫМИ В СОВРЕМЕННОЙ РОССИИ *
}

\author{
ЛИДИЯ ПРОКОФЬЕВА, АННА МИРОНОВА
}

\begin{abstract}
Статья посвящена проблеме помощи пожилому населению в России со стороны межсемейных сети поддержки, а также участию пожильх в межсемейных обменах. Данные репрезентативных обследований (Российский мониторинг экономического положения и здоровья населения - РМЭЗВШЭ 2013 г.; обследование Росстата Комплексное обследование уровня жизни - КОУЖ 2011 г.) показывают важность для пожильх людей родственного окружения, которое выступает не только источником материальной поддержки гораздо более высокого уровня, чем социальная помощьь, но и оказывает весь спектр необходимых пожилому населению услуг, включая психологическую помощь в адаптации этой возрастной группы к новому этапу жизненного циикла после выхода с рынка труда.

Даётся определение целевой группы исследования и ее сочиально-демографические характеристики, включая особенности регионального расселения по территории страны. Основной акцент в исследовании делается на наиболее уязвимой группе пожильх (одиноко проживающие лица или отдельно живущие супружеские пары), для которой в сегодняшних условиях неразвитости сферы услуг для пожильх родственная и соседская помощь оказываются жизненно необходимыми.
\end{abstract}

Ключевые слова: пожилое население, межсемейные обмены, социальная поддержка.

Проблема условий жизни пожилого населения, его материального положения и социального обслуживания остро стоит на повестке дня в современной России. В условиях низкого уровня пенсионного обеспечения введенные доплаты к пенсиям до прожиточного минимума могут лишь поддержать пожилых на крайне низком уровне потребления. Принимаемые для развития системы социального обслуживания решения призваны расширить спектр услуг для пожилых, сделать их более доступными. Однако принятие решений еще не означает их быструю реализацию. В этих условиях единственным источником материальной поддержки и помощи услугами оказываются близкие люди, будь то родные или соседи.

Расширенные семьи, тесные семейные, соседские, дружеские связи и взаимная поддержка деньгами, продуктами или услугами остаются частым явлением в России. В периоды относительно благополучной экономической ситуации это своего рода элемент образа жизни, в периоды кризиса - важный, а иногда и единственный способ выживания. Подобный способ адаптации к сложным социально-экономическим условиям можно отнести к категории архаичных, но он реально помог многим семьям в трудный период жизни и помогает до сих пор семьям группы риска бедности и социальной исключенности [Овчарова, Прокофьева 2000; Фадеева 1999; Денисенко 2007]. Близкие родственники являются тем социальным капиталом, на который можно опереться в трудной жизненной ситуации и который помогает решать важные проблемы текущей жизни.

ЛИДИЯ МИХАЙЛОВНА ПРОКОФЬЕВА. НАЦИОНАЛЬНЫЙ ИССЛЕДОВАТЕЛЬСКИЙ УНИВЕРСИТЕТ «ВЫСШАЯ ШКОЛА ЭКОНОМИКИ», РОССИЯ. E-mail: lprokofieva@hse.ru

АННА АЛЕКСЕЕВНА МИРОНОВА. НАЦИОНАЛЬНЫЙ ИССЛЕДОВАТЕЛЬСКИЙ УНИВЕРСИТЕТ «ВЫСШАЯ ШКОЛА ЭКОНОМИКИ», Россия. E-mail: amironova@hse.ru

СТАТЬЯ ПОСТУПИЛА В РЕДАКЦИЮ В ИЮЛЕ 2015 Г.

* ИССЛЕДОВАНИЕ ОСУЩЕСТВЛЕНО В РАМКАХ ПРОГРАММЫ ФУНДАМЕНТАЛЬНЫХ ИССЛЕДОВАНИЙ НИУ ВШЭ В 2015 Г. 
Статья состоит из двух частей, первая представляет используемое в исследовании определение пожилого населения, его социально-демографические характеристики и особенности расселения (тип поселения, регионы), вторая содержит описание масштабов и видов межсемейной поддержки пожилых людей.

\section{ПОЖИЛЫЕ КАК СОЦИАЛЬНО-ДЕМОГРАФИЧЕСКАЯ КАТЕГОРИЯ}

Возрастная группа «пожилых» не всегда понимается однозначно. Чаще всего она ассоциируется с людьми пенсионного возраста. В большинстве развитых стран к пожилым людям относят лиц в возрасте 65 лет и старше [World Health Organization 2015], что совпадает с окончательным выходом на пенсию. Однако возраст выхода на пенсию в России относительно низок, особенно у женщин, и не связан с обязательным уходом от трудовой деятельности, поэтому выделение людей пожилого возраста как группы населения, нуждающегося в помощи и поддержке, заставляет искать границу резкого снижения занятости пенсионеров как условную линию перехода в пожилой возраст. Здесь важно, прежде всего, учитывать возраст, в котором пенсионные выплаты начинают играть ключевую роль в материальном обеспечении индивида. Если в возрастной группе 45-50 лет, когда некоторые профессиональные категории граждан имеют право на досрочный выход на пенсию, доля тех, кто указывает пенсию по старости как основной источник, колеблется в пределах 10\%, то к возрасту 65 лет этот показатель составляет уже 90\%. В первые годы после выхода на пенсию большинство людей продолжают трудиться, поэтому в 55-59 лет у женщин и 60-64 года у мужчин доходы от трудовой деятельности ещё продолжают играть важную роль. Таким образом, возраст 65 лет для большинства пенсионеров является той границей, после которой резко снижается их материальная обеспеченность. В исследовании межсемейной поддержки пожилых мы ограничили эту группу возрастом 65 лет и старше.

По данным последней переписи (2010 г.) пожилое население составляет 12,7\% населения страны, среди женщин эта доля равна $16,3 \%$, а среди мужчин - 8,8\%. Соотношение мужчин и женщин в этой возрастной группе находится на уровне 1:2, т.е. мужчины составляют лишь примерно треть пожилых. Различие в уровне смертности мужчин и женщин приводит к уменьшению доли мужчин в группах более старшего возраста: от 37\% в возрасте 65-69 лет до 23\% в самой старшей возрастной группе (80 лет и старше).

Тип поселения слабо дифференцирует долю пожилых в общей численности населения: в селах их доля лишь немногим больше (13,4\% против $12,4 \%$ в городах).

С точки зрения регионального расселения распределение пожилых по регионам в большой степени зависит от их размеров - 29\% пожилых живут в 6 самых крупных регионах (Москва, Московская область, Краснодарский край, Санкт-Петербург, Ростовская и Свердловская области). Что касается доли пожилых в населении регионов, то разброс довольно значителен: от 16,6\% в Тульской области до 2,8\% в Чукотском автономном округе при средней доле по всем регионам на уровне $12,7 \%$ (рисунок 1 ). 


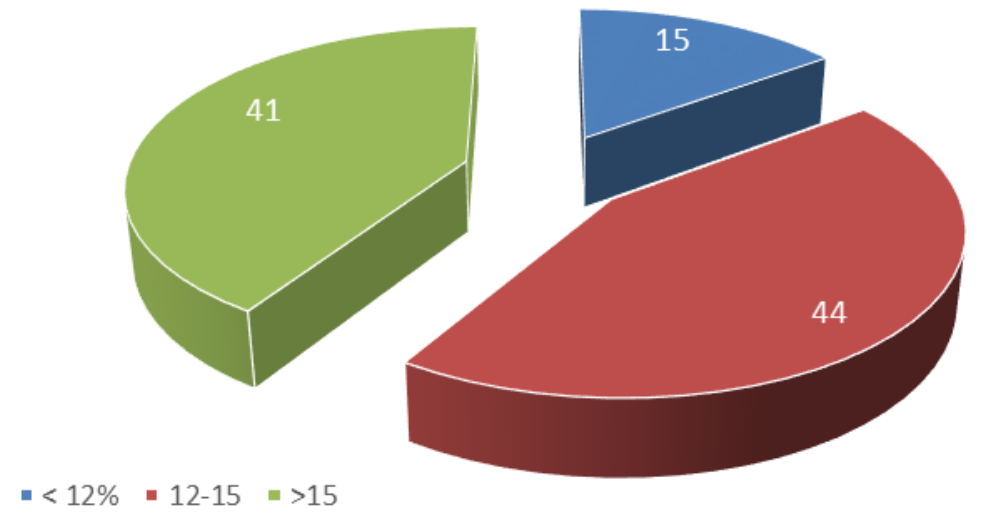

Рисунок 1. Распределение регионов по доле пожилых, \%

Особую группу пожилых составляют те, кто живет отдельно от родственников, поэтому для них помощь в повседневной жизни через межсемейную сеть поддержки особенно актуальна (одиноко проживающие и супружеские пары пожилых). Почти 60\% пожилых живут в домохозяйствах этих двух типов, эта доля практически не меняется с 1994 г. (таблица 1). Вместе с тем внутри этой группы выросла доля пожилых одиночек и уменьшился удельный вес супружеских пар, что связано с ростом смертности мужчин в этот период новейшей истории России.

Таблица 1. Распределение пожилых людей (65+) по типам домохозяйств, Россия микроперепись 1994 г., переписи 2002, 2010 г.

\begin{tabular}{l|r|r|r}
\hline Тип домохозяйства & 1994 & 2002 & 2010 \\
\hline Домохозяйства, состоящие из одного & 25,5 & 26,1 & 29,7 \\
человека & & & 29,6 \\
Домохозяйства, состоящие из одной & 33,8 & 32,8 & 25,0 \\
супружеской пары (простые) & 28,0 & 27,9 & 7,9 \\
Сложные домохозяйства & 7,6 & 7,5 & 7,7 \\
Неполные семьи (постые) & 5,1 & 5,7 & 100,0 \\
Прочие домохозяйства & 100,0 & 100,0 & \\
Итого &
\end{tabular}

Если рассматривать различия между пожилыми мужчинами и женщинами по типу проживания, то мужчины реже живут одни - $16 \%$ против $36 \%$ у женщин, в большинстве своем (52\%) мужчины остаются в старости в паре с супругой (таблица 2).

Таблица 2. Распределение пожилых людей (65+) разного пола и места проживания по типам домохозяйств, Россия перепись 2010 г.

\begin{tabular}{l|r|r|r|r}
\hline Тип домохозяйства & Мужчины & Женщины & Город & Село \\
\hline Домохозяйства, состоящие из одного & 15,9 & 36,0 & 29,1 & 31,2 \\
человека & & & & 32,6 \\
Домохозяйства, состоящие из одной & 52,1 & 19,4 & 28,5 & 23,3 \\
супружеской пары (простые) & 24,2 & 25,4 & 25,6 & 7,7 \\
Сложные домохозяйства & 2,9 & 10,2 & 8,0 & 5,2 \\
Неполные семьи (простые) & 4,9 & 9,0 & 8,7 & 100,0 \\
Прочие домохозяйства & 100,0 & 100,0 & 100,0 & \\
Итого & & & &
\end{tabular}


В сельской местности пожилые чаще живут отдельно от родственников (64\% против $58 \%$ в городах), но зачастую это проживание в доступной близости от взрослых детей, живущих по соседству.

Что касается региональных различий в структуре домохозяйств пожилых людей, то здесь большую роль играют национальные традиции. Так, минимальная доля пожилых, живущих отдельно от родственников, в 2010 г. отмечалась в Республике Ингушетия (6,1\% среди пожилых), а максимальная - в Курганской области (67,3\%) при средней по стране на уровне 59\% (рисунок 2).

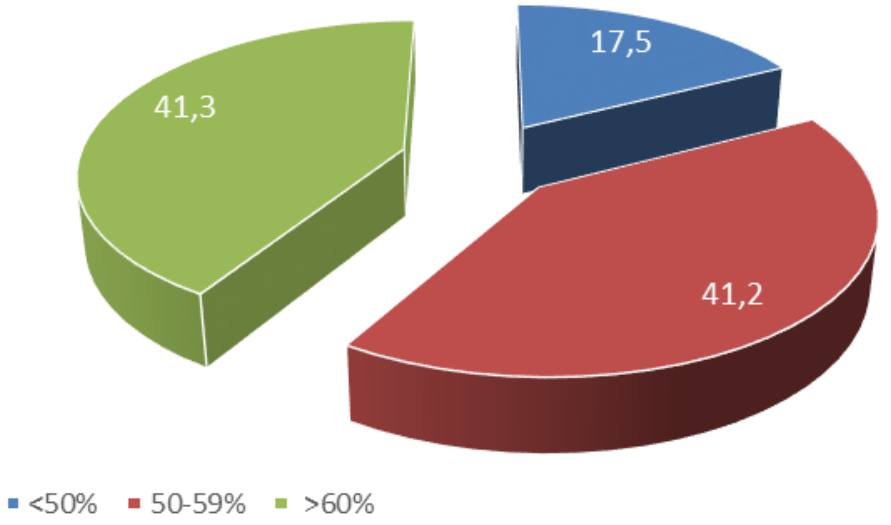

\section{Рисунок 2. Распределение регионов по доле пожилых, живущих отдельно от родственников, \%}

Именно группа пожилых, живущих отдельно от родственников, является наиболее социально уязвимой с точки зрения потребности в повседневном уходе и материальной поддержке.

\section{МЕЖСЕМЕЙНАЯ СЕТЬ ПОДДЕРЖКИ ПОЖИЛЫХ ЛЮДЕЙ}

Близкие родственники являются тем социальным капиталом, на который пожилые люди могут опереться в трудной жизненной ситуации и который помогает решать важные проблемы текущей жизни. Помощь родственников становится значимой и незаменимой для престарелых в условиях недостаточного развития или даже отсутствия в России государственных сетей, берущих на себя в случае необходимости заботу о них (дома для престарелых с высоким качеством обслуживания и т.д.). Существование платных услуг такого рода не снимает проблему, поскольку из-за высокой стоимости они практически недоступны большинству российских семей.

В российском контексте определение межсемейной солидарности включает и совместное проживание нескольких поколений, что является редким явлением в европейских странах (исключая Юг Европы). Аккумулирование полностью или частично средств всех поколений, живущих в одном домохозяйстве, позволяет наиболее слабым его звеньям не выпадать в состояние бедности. Тем не менее наибольшее внимание необходимо уделять случаям, когда пожилые одиночки или супружеские пары живут отдельно и 
нуждаются в материальной поддержке или услугах со стороны. Для анализа выделяются денежные трансферты, обмены в натуральной форме (продукты, вещи), помощь в виде услуг, обмен необходимой информацией, моральная поддержка.

Информационной базой исследования служат данные последней волны обследования ВШЭ «Российский мониторинг экономического положения и здоровья населения» 2013 г. (РМЭЗ) и обследования Росстата «Комплексное обследование уровня жизни» 2011 г. (КОУЖ) ${ }^{1}$. Каждое из этих обследований имеет свою специфику сбора данных и тематики, однако оба включают в программу блок вопросов, касающихся межсемейной помощи и поддержки, в том числе пожилых людей, живущих отдельно от родственников.

\section{Виды и масштабы межсемейной поддержкки}

Как показывают специальные обследования, основной формой материальной помощи является финансовая - регулярная или время от времени в случае необходимости, например, в виде оплаты дорогостоящего лечения, оплаты отдыха, учебы, покупки квартиры или машины. Другой формой материальной помощи является поддержка продуктами питания, в основном выращенными на собственном приусадебном или садовом участке. Эта форма межсемейной взаимопомощи чаще присутствует в сельской местности или в небольших городах, где образ жизни мало отличается от сельского, жители же крупных городов в основном получают такую помощь от родственников или друзей, живущих в селах [Народонаселение... 2013].

Бесплатные услуги (оказываемые или получаемые) охватывают различные стороны жизнедеятельности семьи: от элементарной помощи в быту (стирка, уборка, покупка продуктов, приготовление еды), ухода за детьми и престарелыми до строительства или ремонта дома, пошива одежды, предоставления своего жилья для проведения отпуска родным и друзьям. Кроме того, помощь может заключаться в бесплатном оказании профессиональных консультаций и услуг (медицинских, юридических, педагогических), а также в устройстве на работу или в поиске дополнительной работы. Все эти виды межсемейной солидарности, имевшие место и в советский период, сегодня приобретает особую ценность в связи с удорожанием социальной инфраструктуры в городах и почти полным ее исчезновением в сельской местности.

Материалы обследований последних лет позволили определить охват домохозяйств разного типа, в том числе домохозяйств пожилых людей, тем или иным видом взаимопомощи.

\footnotetext{
${ }^{1}$ Информационной базой исследования межсемейной сети поддержки пожилых людей в современной России послужили материалы КОУЖ, выборка 10 тыс. домохозяйств и РМЭЗ, выборка 6150 домохозяйств. Оба обследования реализованы на выборках, репрезентативных для России в целом, и содержат информацию об участии населения в межсемейной сети поддержки, ее формах и масштабах (http://www.hse.ru/rlms/ - PMЭ3; http://www.gks.ru/free_doc/new_site/KOUZ/survey0/index.html - КОУЖ). Наиболее широко спектр межсемейной взаимопомощи представлен в РМЭЗ, где рассматривается и субъективная оценка межсемейной взаимопомощи ее получателем, а также роль системы взаимоподдержки в случае сложной жизненной ситуации. Обследование КОУЖ акцентирует внимание на межпоколенных связях (родители - взрослые дети), а также роли родственников и знакомых в обеспечении ухода за больными.
} 
Mатериальные трансферты. Помощь родным деньгами или в натуральной форме оказывают $43 \%$ домохозяйств. Масштабы этого вида поддержки мало зависят как от уровня дохода семьи, так и от места проживания. Что касается состава семьи, то опрос РМЭЗ показал, что по-прежнему помощь оказывает старшее поколение молодым: самая высокая частота получения помощи встречается у молодых супругов и у молодежи, выделившейся из родительской семьи (32 и 55\% соответственно).

Данные по межсемейным обменам показывают, что материальная помощь может получаться и оказываться, а иногда это происходит одновременно, но потоки помощи не обязательно встречные. В общей системе межсемейных трансфертов участвуют 45\% домохозяйств, из них четверть только помогают другим, 15\% только получают поддержку, а 5\% и получают, и помогают сами (таблица 3 ).

\section{Таблица 3. Распределение домохозяйств по типу участия в межсемейных трансфертах (межсемейные обмены за последние 30 дней), \%}

\begin{tabular}{|c|c|c|c|c|c|}
\hline \multirow[b]{2}{*}{ Тип домохозяйства } & \multirow{2}{*}{$\begin{array}{l}\text { Участвовали в } \\
\text { трансфертах }\end{array}$} & \multicolumn{3}{|c|}{ В том числе: } & \multirow{2}{*}{$\begin{array}{c}\text { Не } \\
\text { участвовали }\end{array}$} \\
\hline & & $\begin{array}{c}\text { помогали } \\
\text { сами }\end{array}$ & получали & $\begin{array}{c}\text { и помогали, } \\
\text { и получали }\end{array}$ & \\
\hline $\begin{array}{l}\text { Все домохозяйства } \\
\text { из них: }\end{array}$ & \multicolumn{4}{|c|}{ из них: } & 55,0 \\
\hline & \multicolumn{5}{|c|}{ по типу поселения: } \\
\hline городские & 44,2 & 23,6 & 15,8 & 4,8 & 55,8 \\
\hline сельские & 47,0 & 26,8 & 14,7 & 5,5 & 53,0 \\
\hline \multicolumn{6}{|c|}{ по демографическому типу домохозяйства: } \\
\hline одиночки в возрасте до 30 лет & 68,7 & 6,8 & 55,1 & 6,8 & 31,3 \\
\hline одиночки старшего возраста (65+) & 47,8 & 26,2 & 15,8 & 5,8 & 52,2 \\
\hline супруги без детей (молодые) & 52,8 & 14,6 & 31,5 & 6,7 & 47,2 \\
\hline $\begin{array}{l}\text { супруги без детей (старший } \\
\text { возраст) }\end{array}$ & 48,3 & 36,3 & 6,2 & 5,8 & 51,7 \\
\hline супруги с детьми & 47,6 & 10,7 & 31,7 & 5,5 & 52,4 \\
\hline неполные семьи с детьми & 51,4 & 11,0 & 35,9 & 4,5 & 48,6 \\
\hline сложные домохозяйства с детьми & 31,5 & 13,3 & 14,3 & 4,0 & 68,5 \\
\hline прочие домохозяйства & 39,7 & 25,4 & 11,9 & 3,7 & 60,3 \\
\hline
\end{tabular}

По степени участия в межсемейных трансфертах пожилые одиночки и супруги старшего возраста выступают скорее в роли доноров, чем получателей помощи. Таким образом, преимущественное направление поддержки от старшего поколения к младшему, которое отмечалось в ходе обследований конца 1990-х - начала 2000-х годов, сегодня не изменилось [Денисенко 1999; Овчарова, Прокофьева 2000; Иванова 2003].

Нужно отметить, что все выделенные нами типы домохозяйств в той или иной степени оказываются объектом оказания помощи со стороны родственников и друзей: минимальный процент получающих помощь составил 6\%.

По сравнению с городским населением, где направление помощи от старшего поколения к младшему выражено более сильно, на селе можно видеть два почти равных по частоте встречных потока: от родителей к молодым детям, уже живущим самостоятельно, и от детей к родителям (40 и 36\% соответственно). Это говорит о большей нуждаемости старшего поколения сельских жителей в дополнительной материальной поддержке близких родственников. Помощь от друзей гораздо чаще отмечают городские семьи, чем живущие 
в сельской местности. Традиционная межсоседская взаимопомощь в сельской местности сохраняется, однако в большей мере она принимает формы обмена услугами или натуральной помощи продукцией своего личного хозяйства.

Анализ источников получения материальной помощи показывает, что основными донорами являются родители (почти 50\%), что подтверждает преобладающую направленность помощи от старшего поколения к младшему (таблица 4). Старшему поколению помогают не только дети, но и внуки, другие родственники и друзья, но среди них основную роль играет поддержка детей (84-89\%).

Помощь услугами. Кроме материальной поддержки, выражающейся в монетарной или натуральной помощи, семьи активно участвуют в обмене услугами. Среди этих услуг выделяются помощь по дому и в личном подсобном хозяйстве, уход и воспитание детей, уход за престарелыми и больными родственниками. Получение такого вида услуг отметили $16,5 \%$ домохозяйств, причем более половины случаев падает на помощь в повседневной жизни и еще треть - в уходе и воспитании детей.

Среди демографических типов домохозяйств помощь по дому и в личном подсобном хозяйстве чаще всего получают пожилые одинокие люди и супруги (41 и $33 \%$ соответственно). Семьи с детьми реже нуждаются в такого вида помощи, но ее получают $15-17 \%$ семей с детьми. Внимание к ним со стороны родственников и друзей выражается чаще всего в поддержке по уходу и воспитанию детей - эту помощь получают почти 50\% семей с детьми (таблица 5).

Таблица 4. Распределение получаемых материальных трансфертов по их источнику (получение трансфертов в последние 30 дней), \%*

\begin{tabular}{|c|c|c|c|c|c|c|}
\hline Тип домохозяйства & $\begin{array}{c}\text { От } \\
\text { родителей }\end{array}$ & $\begin{array}{c}\text { От } \\
\text { детей }\end{array}$ & $\begin{array}{c}\text { От бабушек/ } \\
\text { дедушек }\end{array}$ & $\begin{array}{c}\text { От } \\
\text { внуков }\end{array}$ & $\begin{array}{c}\text { От других } \\
\text { родственников }\end{array}$ & $\begin{array}{c}\text { От } \\
\text { друзей }\end{array}$ \\
\hline \multirow[t]{2}{*}{$\begin{array}{l}\text { Все домохозяйства } \\
\text { из них: }\end{array}$} & 47,4 & 27,4 & 6,7 & 2,2 & 15,3 & 11,0 \\
\hline & \multicolumn{6}{|c|}{ по типу поселения: } \\
\hline городские & 49,7 & 24,7 & 8,3 & 1,8 & 15,7 & 12,1 \\
\hline \multirow[t]{2}{*}{ сельские } & 40,3 & 35,5 & 7,7 & 3,6 & 14,0 & 7,6 \\
\hline & \multicolumn{6}{|c|}{ по демографическому типу домохозяйства: } \\
\hline одиночки в возрасте до 30 лет & 89,2 & - & 22,6 & - & 9,7 & 9,7 \\
\hline одиночки старшего возраста & & 84,3 & 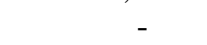 & 13,3 & 12,2 & 4,4 \\
\hline супруги без детей (молодые) & 94,7 & - & 19,3 & - & 7,0 & 5,3 \\
\hline $\begin{array}{l}\text { супруги без детей (старший } \\
\text { возраст) }\end{array}$ & - & 88,7 & - & 4,2 & 12,7 & 2,8 \\
\hline супруги с детьми & 91,2 & - & 13,1 & - & 15,1 & 7,1 \\
\hline неполные семьи с детьми & 68,0 & 8,6 & 9,4 & - & 21,9 & 18,8 \\
\hline $\begin{array}{l}\text { сложные домохозяйства с } \\
\text { детьми }\end{array}$ & 69,7 & 5,6 & 11,8 & - & 24,2 & 18,0 \\
\hline прочие домохозяйства & 41,8 & 25,8 & 7,2 & 1,5 & 27,8 & 22,4 \\
\hline
\end{tabular}

Примечание: * - помощь могла приходить из нескольких источников, поэтому сумма по строке не равна $100 \%$.

Источник: расчет на данных РМЭЗ.

Помощь по уходу за больными и престарелыми оказывается в основном пожилым одиноким людям, и здесь уже дети играют основную роль (почти 70\% случаев), реже подключаются внуки или соседи (менее 30\%). Если в многопоколенном домохозяйстве 
пожилой человек нуждается в уходе в связи с возрастом или болезнью, то его чаще всего осуществляет кто-то из членов семьи (3/4 случаев) или родственники, живущие отдельно, знакомые (16\%), очень редко (4\%) приглашаются специальные люди, услуги которых оплачиваются. При этом на вопрос анкеты: «Хотели бы Вы нанять человека для ухода за больным или престарелым членом семьи?», - 80\% домохозяйств ответили отказом, а для тех, кто хотел бы пригласить специального человека, главным препятствием является недостаток средств для этого в бюджете семьи. Только $2 \%$ домохозяйств, заявивших о своем желании нанять сиделку к больному или пожилому члену семьи, не могут этого сделать из-за отсутствия предложения («хотели бы, но не можем найти»), следовательно, речь идет о достаточно высокой стоимости услуг по уходу, которые оказываются недоступными семьям.

Таблица 5. Доля домохозяйств, получавших помощь в виде тех или иных услуг, \%

\begin{tabular}{|c|c|c|c|}
\hline Тип домохозяйства & $\begin{array}{c}\text { Работа по дому и на } \\
\text { личном подворье }\end{array}$ & Уход за детьми & $\begin{array}{c}\text { Уход за больными } \\
\text { и престарелыми }\end{array}$ \\
\hline \multirow{2}{*}{$\begin{array}{l}\text { Все домохозяйства } \\
\text { из них }\end{array}$} & \multicolumn{2}{|l|}{19,6} & 7,5 \\
\hline & \multicolumn{2}{|c|}{ по типу домохозяйства: } & \\
\hline одиночки в возрасте до 30 лет & 4,7 & - & 0,0 \\
\hline одиночки старшего возраста (65+) & 40,5 & - & 23,0 \\
\hline супруги без детей (молодые) & 3,1 & - & 1,1 \\
\hline супруги без детей (старший возраст) & 33,0 & - & 15,7 \\
\hline супруги с детьми & 15,1 & 50,1 & 0,3 \\
\hline неполные семьи с детьми & 16,5 & 45,5 & 0,7 \\
\hline сложные домохозяйства с детьми & 8,2 & 16,1 & 1,8 \\
\hline прочие домохозяйства & 12,5 & 4,4 & 5,7 \\
\hline
\end{tabular}

Источник: расчет на данных РМЭЗ.

По данным опроса Росстата (КОУЖ), только 23\% из тех, кто прибегал к чьей-либо помощи для самообслуживания и другой ежедневной деятельности, состояли на социальном обслуживании в органах социальной защиты населения, но 58,3\% получали помощь от детей.

Для пожилых людей, испытывающих потребность в медицинской помощи (в том числе в длительном медицинском наблюдении, помощи и уходе вследствие хронического заболевания или инвалидности; в восстановительном лечении в период реабилитации, в медицинской помощи при обострении хронических заболеваний, при недомоганиях, простудных заболеваниях), кроме медицинских работников, важным элементом поддержки и ухода за больными выступают родные или знакомые $(18,3 \%)$ и лишь в $2,2 \%$ случаев социальные работники (таблица 6).

Таким образом, для описания взаимосвязи между участием семьи и государства в уходе за пожилыми наиболее подходящей является «комплементарная модель». Согласно ей к помощи государства прибегают в основном тогда, когда потребности пожилого человека превышают возможности семьи в обеспечении поддержки. Поэтому активное участие семьи в уходе за пожилыми родственниками позволяет государству экономить на расходах [Keefe 2012]. 
Обследование Росстата (КОУЖ) дает более полную информацию о структуре межпоколенной взаимопомощи (родители - дети). Согласно этим данным 81,4\% пожилых людей (в возрасте старше 65 лет), имеющих отдельно проживающих детей, в той или иной форме получали от них помощь, $12 \%$ пожилых не получали никакой помощи, 6,6\% либо затруднялись ответить, либо утверждали, что в помощи нет необходимости.

\section{Таблица 6. Источник медицинской помощи для пожилых людей}

\begin{tabular}{lr}
\hline Из тех, кто испытывает потребность в медицинской помощи, получают её от & $\%$ \\
\hline лечащего врача & 62,7 \\
родных, знакомых & 18,3 \\
медицинской (патронажной) сестры & 6,3 \\
справляется самостоятельно & 6,2 \\
социального работника & 2,2 \\
знакомого врача или знакомого медицинского работника & 1,7 \\
специально нанятого человека & 0,2 \\
никто не оказывает медицинскую помощь & 2,4 \\
Итого & 100 \\
\hline чикк: КОУЖ.
\end{tabular}

Чаще всего дети ухаживают за своими пожилыми родителями во время болезни, помогают по хозяйству или оказывают другую помощь; помощь от детей в виде денег и покупки продуктов пожилые люди получают значительно реже (рисунок 3).

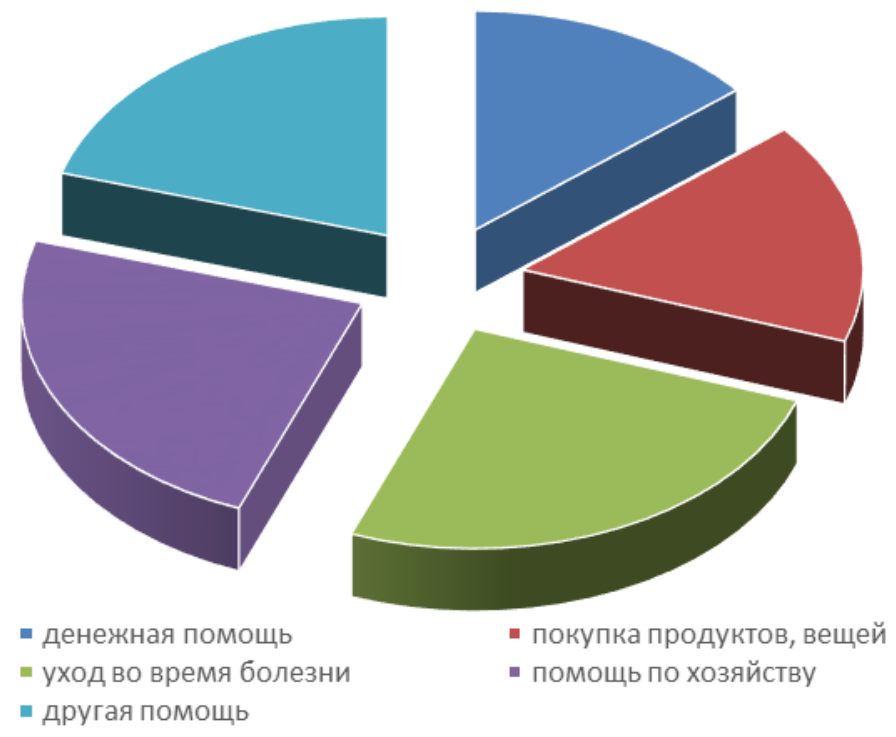

Рисунок 3. Тип помощи, которую пожилые получают от детей, \%

Источник: КОУЖ.

Обследование РМЭЗ также подтверждает выводы о том, что сами пожилые продолжают играть роль доноров для своих детей. Так, 64,3\% пожилых людей помогают своим детям, живущим отдельно, $34,9 \%$ не помогают, $0,8 \%$ затруднились ответить. Большинство (67,6\%) тех, кто не помогает своим детям, объясняют это тем, что дети не нуждаются в их поддержке.

Наиболее распространённым типом поддержки взрослых детей со стороны пожилых родителей является помощь в воспитании внуков, а также помощь в виде денег и продуктов. 
Реже всего пожилые родители оплачивают своим детям жильё и покупают вещи (рисунок 4).

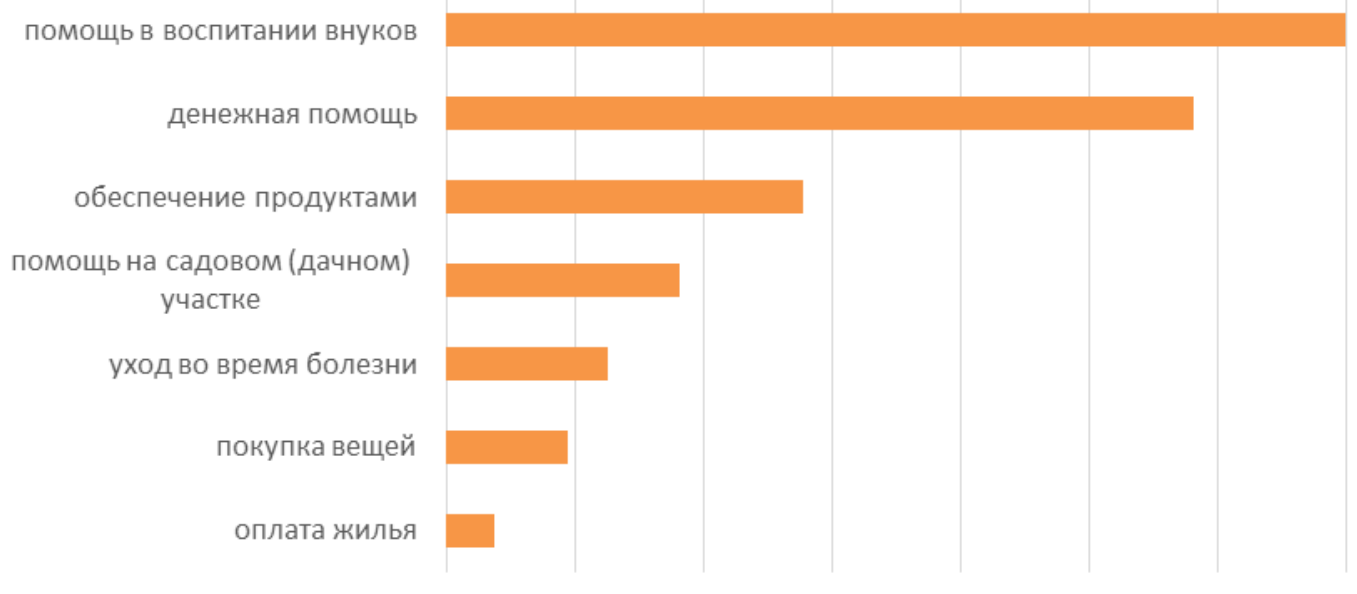

Рисунок 4. Тип помощи, которую пожилые оказывают взрослым детям, \%

Источник: КОУЖ.

В наибольшей степени в воспитание внуков вовлечены бабушки/дедушки в возрасте от 60 до 69 лет. До 65 лет доля участия старших родителей в воспитании внуков растет, а затем начинается тенденция к снижению - дети вырастают, старшие родственники стареют. Но и после 70 лет в среднем четверть пожилых продолжают регулярно заниматься внуками (рисунок 5).

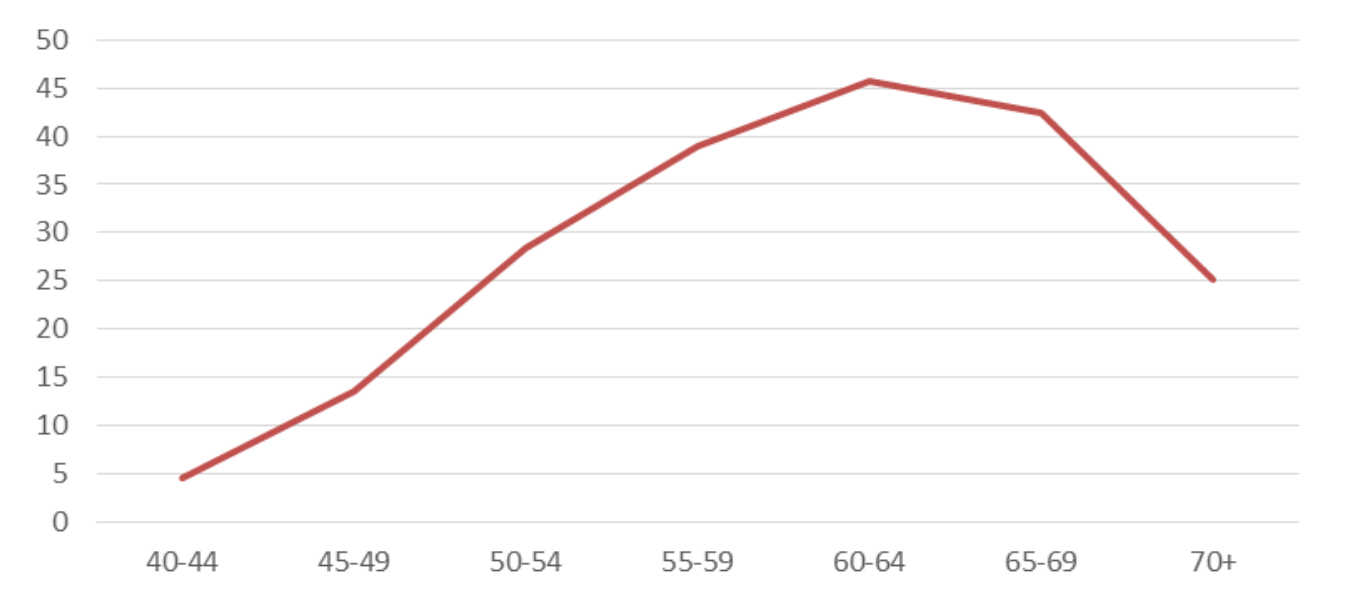

Рисунок 5. Доля бабушек/дедушек, помогающих в воспитании внуков, \%

Источник: КОУЖ.

Возраст родителей является важным фактором, определяющим направление межсемейных трансфертов. Почти во всех возрастных группах родителей доля тех, кто помогает своим отдельно живущим детям, выше, чем доля родителей, получающих денежную помощь от детей. Резкое сближение потоков происходит как раз к возрасту 65 лет, а в возрастной группе 70 лет и старше доля родителей, получающих от детей денежную помощь $(32,2 \%)$ начинает превышать долю тех, кто продолжает поддерживать своих детей деньгами $(31,6 \%)$, хотя различие и невелико (рисунок 6). 


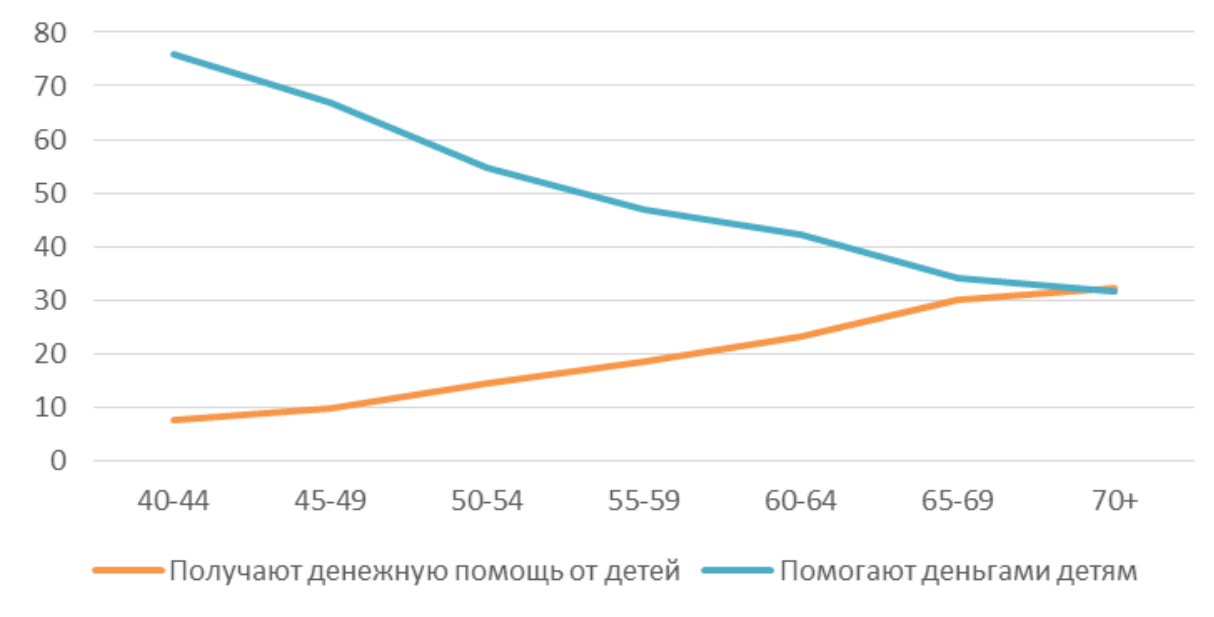

Рисунок 6. Доля родителей, получающих денежную помощь от детей или помогающих детям, в каждой возрастной группе, \%

Источник: КОУЖ.

Фактор возраста играет значимую роль и в динамике активной поддержки престарелых в случае болезни: по мере перехода к более старшим возрастным группам заметен рост случаев ухода за престарелыми во время болезни, а для родителей в возрасте от 70 лет и старше доля получающих помощь от детей составляет 44,7\% (рисунок 7).

Роль межсемейной сети поддержки в жизни семей. Широкое распространение взаимной межсемейной поддержки является важным элементом образа жизни семей. Она дает ощущение надежного источника помощи, который в случае необходимости можно использовать, ощущение защищенности в трудной жизненной ситуации, который более доступен для большинства семей, чем социальная поддержка.

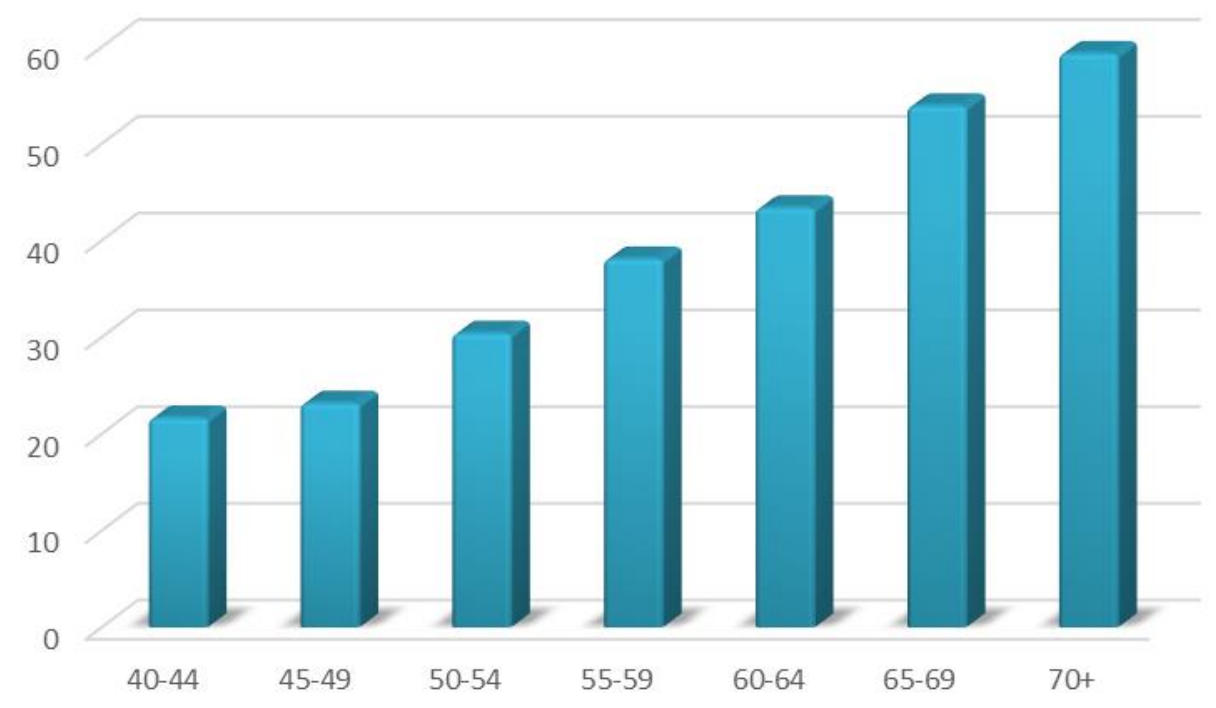

Рисунок 7. Доля родителей, получающих от детей уход во время болезни, в каждой возрастной группе, \%

Источник: КОУЖ. 
Кроме материальной поддержки и помощи услугами, семьи отмечают важность моральной поддержки, получаемой от родственников и друзей в случае сложной ситуации, проблем в семье и личной жизни. Только 5\% респондентов отметили отсутствие такой поддержки, а большинство получает ее «практически всегда» $(53 \%)$ или «часто» $(27 \%)$.

Частые контакты с родственниками, живущими отдельно, способствуют усилению взаимообменов между семьями. Как показали данные опроса РМЭ3, 44\% семей, у которых есть родственники, живущие отдельно, видятся с ними практически каждый день $(26 \%)$ или несколько раз в неделю (18\%) и только менее 4\% видятся с ними крайне редко (реже, чем раз в год) или не имеют никаких контактов. Главной причиной отсутствия контактов в большинстве случае является удаленность проживания (60\% ответов).

Таким образом, включенность в межсемейную сеть поддержки не только материально помогает семьям в трудной жизненной ситуации, но и избавляет большинство из них от социальной исключенности, изолированности от социума.

Доля домохозяйств, получивших материальную помощь от родственников или друзей в последние 30 дней перед проведением опроса, составила $24 \%$. Доля материальной поддержки от родственников и друзей в доходах семей-получателей составляет в среднем $21 \%$, однако она более значима для некоторых категорий домохозяйств: помощь родственников является определяющей доходы молодежи, живущей отдельно от родственников (55\%), и составляет треть бюджета неполных семей с детьми (таблица 7).

\section{Таблица 7. Доля частных трансфертов в доходах домохозяйств разного типа и их соотношение с прожиточным минимумом (ПМ) домохозяйства, \%}

\begin{tabular}{l|c|c}
\hline Тип домохозяйства & $\begin{array}{c}\text { Доля частных трансфертов } \\
\text { в доходах домохозяйств- } \\
\text { получателей }\end{array}$ & $\begin{array}{c}\text { Соотношение } \\
\text { материальной помощи с } \\
\text { ПМ на домохозяйство* }\end{array}$ \\
\hline Все домохозяйства & 21,3 & 50,5 \\
одиночки в возрасте до 30 лет & из них по типу домохозяйства: \\
одиночки старшего возраста (65+) & 54,7 & 85,0 \\
супруги без детей (молодые) & 31,5 & 84,4 \\
супруги без детей (старший возраст) & 21,7 & 63,7 \\
супруги с детьми & 27,6 & 72,6 \\
неполные семьи с детьми & 16,7 & 30,9 \\
сложные домохозяйства с детьми & 33,2 & 47,9 \\
\hline
\end{tabular}

Примечание: * - ПМ домохозяйства, рассчитанный с учетом его демографического состава.

Источник: расчет на данных РМЭЗ.

Для пожилых людей, будь то одиночки или супружеские пары, доля материальной помощи родственников в среднем составляет почти треть доходов, состоящих главным образом из пенсии. Если рассматривать размер получаемой помощи в соотношении с ПМ домохозяйств-получателей, то для одиноких пожилых частные трансферты добавляют более $80 \%$ ПМ и для пожилых супругов - чуть меньше (73\%).

Роль межсемейной поддержки оказывается существенно выше, чем значение социальных трансфертов, получаемых семьями. Если под социальными трансфертами понимать пособия, субсидии и доплаты, а также стипендии для студентов, то их доля в 
доходах семей-получателей в среднем составляет менее $10 \%$, что в 2 раза меньше доли помощи родных и друзей (таблица 8).

Для всех выделенных типов домохозяйств помощь родственников играет более важную роль, чем социальная поддержка. Вместе с тем частота оказания социальной помощи намного выше у пожилых, именно они значительно чаще получают различного рода пособия, субсидии и доплаты, чем семьи с детьми (рисунок 6). Сложные многопоколенные домохозяйства с детьми, в состав которых входят пожилые родственники, также часто получают социальную поддержку.

Таблица 8. Доля социальных трансфертов в доходах домохозяйств-получателей (за последние 30 дней), \%

\begin{tabular}{|c|c|c|c|c|}
\hline \multirow[t]{2}{*}{ Тип домохозяйства } & \multirow{2}{*}{$\begin{array}{l}\text { Социальные } \\
\text { трансферты* }\end{array}$} & \multicolumn{3}{|c|}{ В том числе: } \\
\hline & & пособия** & стипендии & $\begin{array}{l}\text { субсидии и } \\
\text { доплаты*** }\end{array}$ \\
\hline \multicolumn{5}{|l|}{ Все домохозяйства } \\
\hline \multirow[t]{2}{*}{ из них } & 8,7 & 8,9 & 8,0 & 7,0 \\
\hline & \multicolumn{4}{|c|}{ по типу домохозяйства: } \\
\hline одиночки в возрасте до 30 лет & 24,4 & - & 25,3 & 22,5 \\
\hline одиночки старшего возраста (65+) & 10,0 & - & - & 10.0 \\
\hline супруги без детей (молодые) & 7,0 & 5,0 & 6,3 & 8,4 \\
\hline супруги без детей (старший возраст) & 6,3 & - & - & 6,3 \\
\hline супруги с детьми & 7,9 & 8,4 & 3,0 & 8,3 \\
\hline неполные семьи с детьми & 12,3 & 11,4 & 6,0 & 13,0 \\
\hline сложные домохозяйства с детьми & 5,0 & 6,0 & 3,2 & 4,7 \\
\hline
\end{tabular}

Источник: расчет на данных РМЭЗ.

Проводимая с 2007 г. социальная политика поддержки семей с детьми дает положительный результат с точки зрения частоты получения пособий семьями: более трети из них являются получателями разного вида пособий на детей, что отразилось на соотношении частоты получения частных и социальных трансфертов в пользу последних. Вместе с тем, как показывают данные обследования, роль социальных пособий значительно менее значима для доходов домохозяйств с детьми, чем помощь родственников (таблицы 7 и 8).

К группам домохозяйств, для которых частота получения помощи от родственников заметно превышает социальную поддержку, относится молодежь, выделившаяся из семьи родителей, и молодые супруги без детей. Именно эти домохозяйства, находящиеся на начальных этапах жизненного цикла и чей доход не позволяет пока обеспечивать свои даже минимальные потребности, нуждаются в поддержке, но социальная политика в отношении этих групп крайне не развита, отличается фрагментарностью и «традиционностью» подхода. Однако помощь этим домохозяйствам должна быть активной: облегчение доступа к профессиональному образованию и к рынку труда (рисунок 8). 


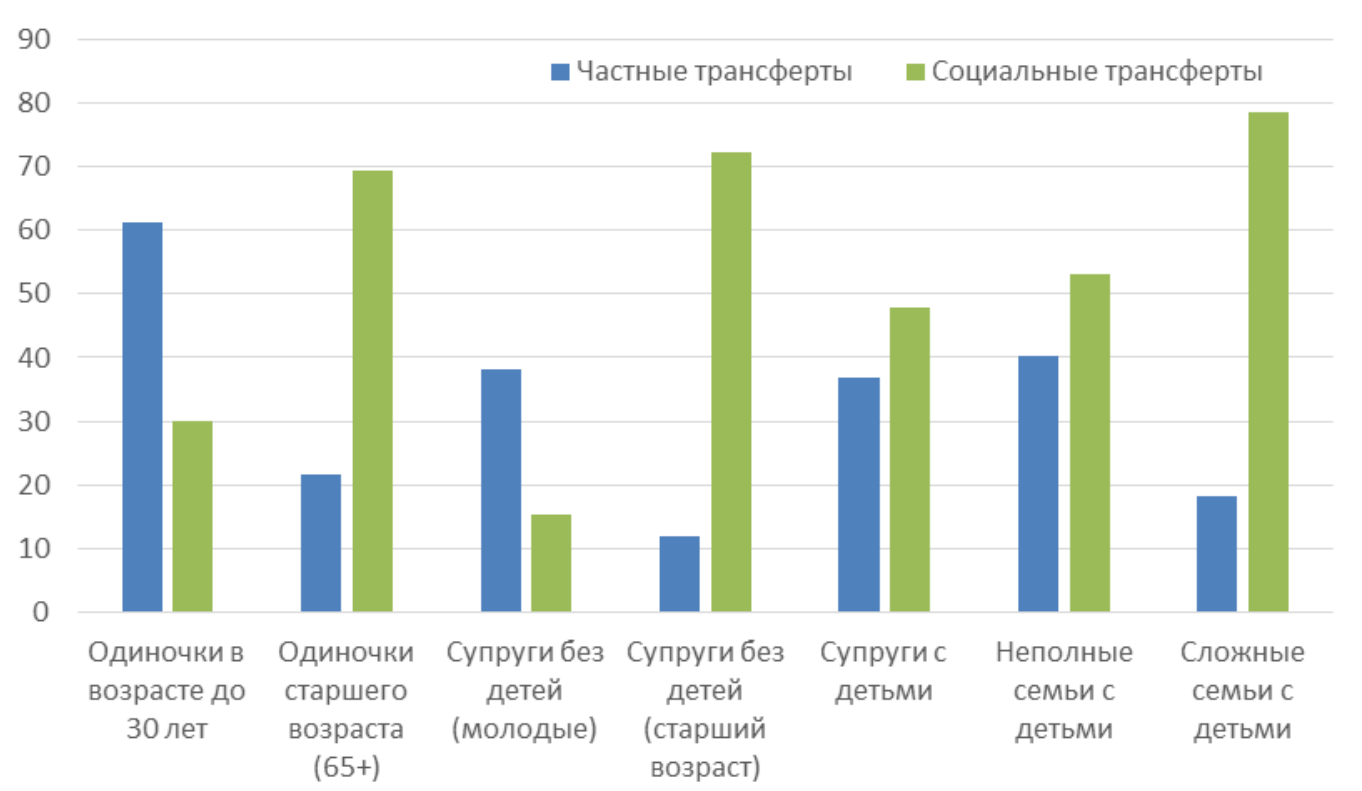

\section{Рисунок 8. Доля получателей социальных и частных трансфертов в разных типах} домохозяйств, \%

Источник: расчет на данных РМЭЗ.

Как уже отмечалось, в межсемейных материальных обменах пожилые даже старших возрастов часто выступают как «доноры», а не получатели помощи (таблица 3). Вместе с тем денежная помощь - это далеко не единственный вид межсемейной поддержки.

Важность межсемейной поддержки пожилые отмечают в своих интервью, в частности проведенных в Ростовской области в рамках международного проекта Российского гуманитарного научного фонда (РГНФ) [Прокофьева, Корчагина и др. 2014]. Особенно часто пожилые отмечают обоюдность обменов, хотя они могут и не быть по значимости одного порядка: «Ни деньгами, ни вещами, ни продуктами мы помочь не можем, но сидим с внуками, другое что помочь можем... советом, например» (пожилые супруги); «Внучка звонит, говорит - подкинь бабушка, я кладу ей на телефон 50 рублей и внуку тоже. Другие родственники мне помогают деньгами, в уборке по дому, поддерживают нас. Я с маленькими сижу, да и советом помогу» (пенсионерка 70 лет, живет с матерью); «Операџию мне сделали, так дочка и сын помогли и материально, и заботились. У меня хорошие дети - на них полагаюсь. А я с внучкой на занятия хожу, в школу, на танцьы - живу ее успехами» (пенсионерка 65 лет). Для пожилых важно быть полезными: «Я себя чувствую комфортно, если у меня есть возможность быть полезной, помогать детям, внукам. Они мне помогают, конечно - половину платы ЖКУ берут на себя» (одинокая пенсионерка, 81 год). Отсутствие близких родственников заменяется соседскими взаимообменами, пусть и незначительными, но это отмечается пожилыми людьми как поддержка и необходимое социальное окружение: «Соседи иногда продуктами мне помогают. А мне и дать нечего. Только помощь свою могу предложить, когда нужно. Ну и пирожками балую иногда» (одинокая пенсионерка, 68 лет).

Результаты качественных интервью показали, что практически все опрошенные, независимо от возраста и материального положения, говорили о включенности в 
межсемейную или дружескую сеть поддержки иногда в активной фазе, иногда рассматривая обращение за помощью к родственникам или друзьям как потенциально возможный выход из положения. При этом респонденты всегда указывают на ответную помощь, которую они оказывают своим родным, пусть даже и не в сопоставимом по значимости виде.

\section{ФЕНОМЕН СОХРАНЕНИЯ АКТИВНОЙ МЕЖСЕМЕЙНОЙ ПОДДЕРЖКИ: ТРАДИЦИЯ ИЛИ НЕОБХОДИМОСТЬ?}

Говоря о межсемейной сети поддержки, часто используют термин «традиционность», однако возникает вопрос: насколько эта традиционность является вынужденной в условиях крайне низкого уровня пенсий и слабого развития сети услуг, обращенных к пожилому населению.

Изучение мнения населения по вопросам, относящимся к необходимости семье поддерживать пожилых (вплоть до совместного проживания или даже отказа от карьеры для ухода за ними) показало преобладание именно «традиционной» точки зрения. Но эти ответы не дают понимания того, насколько отвечавшие думали не об абстрактной модели поведения, а о реальной ситуации отсутствия альтернативной поддержки пожилых со стороны государства. Молодежь придерживается иной точки зрения, согласно которой родители не должны брать на себя такую большую ответственность за своих уже взрослых детей, как это принято в России, а развитая система социальной поддержки пожилых со стороны государства должна позволять взрослым детям целиком посвящать себя карьере и одновременно быть спокойными за престарелых родителей (данные обследования «Родители и дети, мужчины и женщины в семье и обществе» - РиДМиЖ) [Lefèvre et al. 2008]. В связи с этим возникает сомнение в сохранении «традиционности» российского общества в следующих поколениях.

Сохранение в России традиций тесной межсемейной взаимопомощи во многом позволяет решать сегодня те социальные проблемы поддержки пожилых, которые не в состоянии пока полностью взять на себя социальные институты. Речь идет о материальной и моральной поддержке, обмене услугами, которые позволяют им выживать в условиях недостаточного развития и доступности специальной сферы услуг для пожилых людей.

Материальная помощь от родственников, друзей, соседей по масштабам распространения и роли в доходах намного превышает социальную и благотворительную помощь, она представляет собой тот дополнительный ресурс, который необходим пожилым на том этапе жизненного цикла, когда их человеческий потенциал уже недостаточен для полноценной жизни. Как показывают результаты обследований, межсемейный обмен не ограничивается поддержкой семей или одиноких людей в трудной жизненной ситуации, это важный элемент социальной жизни, необходимый ареал общения и информирования, моральной поддержки. В случае отхода от «традиционности» чем заменить межсемейную поддержку? 


\section{ЛИТЕРАТУРА}

Денисенко М.Б. (1999). Благосостояние и трансферты пожилых людей в городах России (по материалам обследований в Нижнем Новгороде, Орле и Твери) // Демографические и социально-экономические аспекты старения населения: Вторые Валентеевские чтения: тез. докл., кн.1. / Науч. ред. В.М. Моисеенко. М.: Диалог-МГУ: 150-161.

Денисенко М.Б. (2007). Межпоколенные трансферты // Экономика народонаселения / Под ред. В.А. Ионцева, А.М. Саградова. М.: Инфра: 304-330.

Иванова Е.И. (2003). Пожилой человек в сельской местности: родственные связи и межпоколенные трансферты // Социальная политика: реалии XXI века. Выпуск 1. М.: НИСП: 135-164

Народонаселение современной России: риски и возможности (2013). Раздел «Межсемейные отношения». М.: Экономическое обозрение: 96-108.

Овчарова Л.Н., Л.М. Прокофьева (2000). Бедность и межсемейная солидарность в России в переходный период // Мониторинг общественного мнения: экономические и социальные перемены. №4: 23-31.

Прокофьева Л.М., И.И. Корчагина и др. (2014). Бедность и социальная исключенность глазами разных групп населения // Народонаселение. №4: 61-81.

Фадеева О. (1999). Межсемейная сеть: механизмы взаимоподдержки в российском селе // Неформальная экономика: Россия и мир / Под ред. Т. Шанина. М.: Логос: 183-218.

Keefe J., J. Légaré, P. Charbonneau, Y. Décarie (2012). Intergenerational Support to Older Canadians by Their Adult Children: Implications for the Future // The Family, the Market or the State? Netherlands: Springer: 141-158.

Lefèvre C., L. Prokofieva, I. Korchagina (2008). Une comparaison France-Russie des opinions sur le rôle de la famille dans l'aide aux personnes âgées à partir des enquêtes Genre et Générations. Québec: LAIDELF.

World Health Organization (2015). Definition of an older or elderly person / World Health Organization. URL: http://www.who.int/healthinfo/survey/ageingdefnolder/en/ (дата обращения: 28.09.2015) 


\section{THE ROLE OF INTERFAMILY EXCHANGE IN THE SYSTEM OF MATERIAL SUPPORT AND CARE FOR THE ELDERLY IN MODERN RUSSIA*}

\section{LIDIA PROKOFIEVA, ANNA MIRONOVA}

Lidia Prokofieva. National Research University Higher School of Economics, Russia. E-MAIL: lprokofieva@hse.ru.

Anna Mironova. National Research University Higher School of Economics, Russia. E-MAIL: amironova@hse.ru.

DATE RECEIVED: July 2015.

This article is devoted to the issue of assistance to the elderly from the interfamily support network and the participation of the elderly in interfamily exchanges. Data of representative surveys (RLMS-HSE, 2013, Integrated monitoring of population life conditions in Russia, 2011) show the importance of relatives' support for older people. Relatives provide not only material aid which significantly exceeds the amount of social aid, but also a broad array of necessary services including psychological support in adapting to a new stage of the life cycle after finishing labor activity.

We define the target group of our study and its socio-demographic characteristics, including the distinguishing features of regional location. The main focus of the study is the most vulnerable group of older people: persons living alone and married couples living apart. Due to underdevelopment of the service industry for the elderly, support aid from relatives and neighbors is vital for this group of older people.

Key words: the elderly, interfamily exchanges, social support.

* THE STUDY WAS IMPLEMENTED UNDER THE BASIC RESEARCH PROGRAM AT THE NATIONAL RESEARCH UNIVERSITY HIGHER SCHOOL OF ECONOMICS (HSE) IN 2015.

\section{REFERENCES}

Denisenko M.B. (1999). Blagosostoyanie i transferty pozhilykh lyudey v gorodakh Rossii (po materialam obsledovaniy v Nizhnem Novgorode, Orle i Tveri) [Welfare and transfers of the elderly in Russian cities (based on surveys in Nizhny Novgorod, Orel, and Tver)] // Demograficheskiye i sotsial'no-ekonomicheskiye aspekty stareniya naseleniya: Vtoryye Valenteyevskiye chteniya [Demographic and socio-economic aspects of population aging: Second Valentey reading]: tez. dokl., kn.1. / Nauch. red. V.M. Moiseyenko. M.: DialogMGU: $150-161$.

Denisenko M.B. (2007). Mezhpokolennye transferty [Intergenerational transfers] / Iontsev V.A., Sagradov A.M. (red.) Ekonomika narodonaseleniya [Population economics]. M.: Infra: 304330.

Fadeeva O. (1999). Mezhsemeynaya set': mekhanizmyvzaimopodderzhki v rossiyskomsele [Inter-family network: mechanisms of mutual support in the Russian countryside]. Shanin T. (red.) Neformal'nayaekonomika: Rossiyaimir. [The informal economy: Russia and the world], M.: Logos: 183-218.

Ivanova E.I. (2003) Pozhiloychelovek v sel'skoymestnosti: rodstvennye svyazi i mezhpokolennye transferty [Elderly people in rural areas: family ties and intergenerational 
transfers]. Sotsial'naya politika: realii XXI veka [Social policy: the realities of the twentyfirst century]. Vol.1. M.: NISP: 135-164.

Keefe J., J. Légaré, P. Charbonneau, Y. Décarie (2012) Intergenerational Support to Older Canadians by Their Adult Children: Implications for the Future // The Family, the Market or the State? Netherlands: Springer: 141-158.

Lefèvre C., L. Prokofieva, I. Korchagina (2008) Une comparaison France-Russie des opinions sur le rôle de la famille dans l'aide aux personnes âgées à partir des enquêtes Genre et Générations. Québec: AIDELF.

Narodonaselenie sovremennoy Rossii: riski i vozmozhnosti. Razdel «Mezhsemeynye otnosheniya» (2013) [Population of modern Russia: risks and opportunities. The part "interfamily relationships"]. M.: Ekonomicheskoe obozrenie: 96-108.

Ovcharova L.N., L.M. Prokof'eva (2000) Bednost' i mezhsemeynaya solidarnost' v Rossii v perekhodnyy period [Poverty and inter-family solidarity in Russia during transition period] // Monitoring obshchestvennogo mneniya: ehkonomicheskie I socialnye izmeneniya. №4: 2331.

Prokof'eva L.M., I.I. Korchagina et al. (2014). Bednost' I sotsial'naya isklyuchennost' glazami raznykh grupp naseleniya [Poverty and social exclusion through the eyes of different population groups] // Narodonaselenie. №4: 61-81.

Valenteevskie chteniya: tez. dokl., kn.1 / Nauch. red. V.M. Moiseenko. M.: Dialog-MGU: 150161 [Demographic and socio-economic aspects of aging: The second Valenteyreding: theses, vol.1 / Academic editor V.M.Moiseenko. M.: Dialog-MSU: 150-161].

World Health Organization (2015). Definition of an older or elderly person / World Health Organization. URL: http://www.who.int/healthinfo/survey/ageingdefnolder/en/ (accessed: 28.09.2015). 